\title{
Dynamics of Pseudoperonospora cubensis Sporangia in Commercial Cucurbit Fields in Michigan
}

\author{
L. L. Granke and M. K. Hausbeck, Department of Plant Pathology, Michigan State University, East Lansing 48824
}

\begin{abstract}
Granke, L. L., and Hausbeck, M. K. 2011. Dynamics of Pseudoperonospora cubensis sporangia in commercial cucurbit fields in Michigan. Plant Dis. 95:1392-1400.

Major outbreaks of cucurbit downy mildew have been observed since 2005 in Michigan, the top state for pickling cucumber production in the United States. Airborne concentrations of Pseudoperonospora cubensis sporangia were monitored from 2006 to 2009 in a commercial cucurbit field in each of five Michigan counties. Temperature, relative humidity, leaf wetness, and rainfall were recorded on site in 2008 and 2009. Seasonal and daily trends for sporangial concentrations were examined using loess regression to determine when sporangia were present throughout the growing season. Airborne sporangia were detected from June through September, and concentrations increased

between 8:00 and 13:00 h. Airborne sporangial concentrations were positively correlated with temperature $(r=0.17$ to $0.38, P<0.0001)$ and negatively correlated with relative humidity $(r=-0.16$ to $-0.45, P$ $\leq 0.0046)$ and leaf wetness $(r=-0.14$ to $-0.39, P \leq 0.0001)$ in 2008 and 2009 at all sites. In autoregressive moving average models, sporangial concentrations were negatively related to relative humidity (slope $=-0.03$ to $-1.34, P<0.0496)$ at three of five sites in 2008 and four of five sites in 2009. Hence, sporangia are likely to be airborne above the crop canopy during periods with high temperatures and low relative humidity and leaf wetness.
\end{abstract} during this period. Peak airborne sporangial concentrations occurred
The oomycete Pseudoperonospora cubensis (Berk. \& M.A. Curtis) Rostovzev is the causal agent of cucurbit downy mildew, a devastating disease found throughout cucurbit-growing regions worldwide (54). Downy mildew is one of the most important foliar diseases of cucurbits, and significant losses may occur if the disease is not adequately managed (54). Most cucurbits are susceptible to downy mildew, including cucumber (Cucumis sativus), cantaloupe (C. melo L.), pumpkin (Cucurbita moschata Duchesne ex Poir.), watermelon (Citrullus lanatus (Thunb.) Matsum \& Nakai), squash (Cucurbita pepo L.) (55), and several wild cucurbit species $(38,48)$. Although host resistance introduced in the 1950 s and 1960s effectively limited downy mildew on cucumber in the United States for many years without the use of fungicides, a resurgence of the disease was observed in North Carolina in 2004 (32), and the disease has since become more widespread. Management of downy mildew now requires fungicide applications every 5 to 7 days in cucumber crops $(25,28)$ and every 7 to 10 days in other cucurbit crops (26). In Michigan, major outbreaks of the disease have been observed since 2005, and the cost of additional fungicide applications is estimated to be over $\$ 6$ million annually (M. K. Hausbeck, unpublished). Michigan is the largest producer of pickling cucumber in the United States (2). Downy mildew management has changed cucumber production dramatically and the longterm viability of the industry may be threatened (49).

Survival of $P$. cubensis, an obligate parasite, is dependent on availability of host plants (54). Although oospores have been occasionally observed in both temperate and tropical regions $(5,18,23,30,41)$, germination of oospores has not been reported (54). Thus, it is currently unknown whether oospores play a role in the disease cycle and in pathogen survival (54). The pathogen overwinters in areas with mild winter temperatures that permit cucurbit hosts to be grown year round (5) and in greenhouses (54). Doran (24), Van Haltern (56), and Holmes et al. (31), have suggested that

Corresponding author: M. K. Hausbeck, E-mail: hausbec1@msu.edu

Accepted for publication 2 June 2011.

doi:10.1094/PDIS-11-10-0799

(C) 2011 The American Phytopathological Society
P. cubensis overwinters in frost-free areas of the southern United States and spreads northward each growing season on northerly winds. Ojiambo and Holmes (40) recently proposed that overwintering sources of the pathogen in southern Florida directly contribute inocula to fields in Florida and up to North Carolina; they further suggested that it is likely that Michigan and other states in the Great Lakes and mid-Atlantic regions of the United States receive inocula from the Georgia, South Carolina, the North Carolina border, or from nearby greenhouses that produce cucumber year round. Secondary inocula may be dispersed within a field via rain splash or physical transfer on equipment but within-field transport via wind is the most common means of dispersal (54).

Environmental conditions greatly influence sporangial production, liberation, dispersal, and survival. Sporangial production is affected by temperature, moisture, and light $(43,46)$. Because many $P$. cubensis spores do not survive atmospheric transport, the production of large numbers of spores is necessary for viable sporangia to reach susceptible host plants. Sporangia are liberated from the underside of leaves following a reduction in relative humidity (RH) when hygroscopic twisting movements of sporangiophores actively release sporangia into air currents (36). Hence, sporangia for most downy mildew pathogens, including P. cubensis, are dispersed during the morning and early afternoon $(9,20,26)$ following a decrease in RH (53). When concentrations of spores of $P$. cubensis and other fungal pathogens were monitored in a watermelon field in a study in Florida (51), P. cubensis sporangia were primarily detected in the early to mid-morning, shortly after the dew dried and surface winds increased. Sporangia were not trapped at night (51). Although spore concentrations were monitored from January until July, sporangia were only detected in June when the watermelon crop canopy was fully developed (51). Sporangia were not detected following a dew-less evening but were trapped from 6:00 until 12:00 on the other 9 days monitored in a study conducted in an Israeli cucumber field (20). Although these studies provide valuable information about the dynamics of airborne sporangial concentrations in semitropical and semiarid locations, it would be useful to know whether similar relationships are apparent in temperate regions because the arrival of sporangia is the first step in the initiation of disease.

Following sporangial dispersal, the distance sporangia are carried depends on where in the crop canopy the spores are produced 
and on wind conditions (4). Sporangia may survive up to 16 days during atmospheric transport (16). Survival is affected by temperature, RH (54), and solar radiation (35). Sufficient viable inocula and favorable environmental conditions are necessary for establishment and progress of an epidemic. Airborne sporangial concentrations are the most important biotic factor determining disease onset (15). Symptoms of downy mildew on cucumber are usually only apparent on leaf tissue (54) because zoospores penetrate through stomata on leaves (34). Sporulation may be the first sign of the pathogen when temperatures are below those required for lesion formation (46). Otherwise, small, chlorotic lesions on the adaxial surface of the leaf are the first symptom of infection (16). These chlorotic lesions expand as infection progresses and may become necrotic (39). Lesions on cucumber plants are angular and limited by the leaf veins; lesion edges are irregular on other cucurbit hosts. The coalescence of multiple expanding lesions on a single leaf may result in the whole leaf dying within days (54). P. cubensis may generate copious amounts of sporangia (46), mostly on the abaxial surface of host leaves, if near-saturated RH occurs for $\geq 6 \mathrm{~h}$ (16). Leaf wetness prohibits sporangium production (16). Longer photoperiods have also been shown to enhance the sporulation potential of the pathogen (21). More sporangia were produced under light following a dry, dark period of approximately $4 \mathrm{~h}$ than under light without a dry, dark period (17). Sporangia may form on cucumber at temperatures from 5 to $30^{\circ} \mathrm{C}$, although 15 to $20^{\circ} \mathrm{C}$ is optimal (54). Disease on older leaves has a longer latent period, and the sporangial production potential of the pathogen is lower than on younger leaves (16). Other factors such as the host species and cultivar and the nutritional status of the host may also affect sporulation (16).

The objectives of this study were to (i) examine seasonal and daily trends for $P$. cubensis airborne sporangial concentrations in commercial cucurbit fields across Michigan, where the pathogen does not appear to overwinter; and (ii) determine the influence of temperature, $\mathrm{RH}$, leaf wetness, and rainfall on airborne sporangial concentrations in Michigan.

\section{Materials and Methods}

Monitoring airborne sporangial concentrations and environmental conditions. Airborne sporangial concentrations were moni- tored throughout the growing season at commercial cucurbit farms in five Michigan counties (Table 1): Allegan (2006 to 2009), Bay (2006 to 2009), Cass (2006, 2008, and 2009), Monroe (2006 to 2009), and Saginaw (2006 to 2009). All of the sites (one per county) were planted to cucumber except for the site in Monroe County in 2009, when the spore trap was placed in a pumpkin field adjacent to a large cucumber field, and the site in Cass County in 2006, when the spore trap was in an acorn squash field for the first 40 days of monitoring before being moved to cucumber. At the Cass County 2006 site, cucumber in low tunnels and field-grown cucumber plantings were within $400 \mathrm{~m}$ of the spore trap when it was located in the acorn squash field. Grower cooperators managed each crop according to normal production practices for Michigan, which included fungicide applications (27).

Airborne concentrations of $P$. cubensis sporangia were determined using a Burkard 7-day volumetric spore sampler (Burkard Manufacturing Co. Ltd., Rickmansworth, Hertfordshire, UK), with the orifice approximately $0.5 \mathrm{~m}$ above the ground. The sampling airflow rate was 10 liters/min, and the sampler was set to allow free movement so that the orifice faced the prevailing wind. Sporangia were impacted onto Melinex tapes (Burkard Manufacturing Co. Ltd.) coated with an adhesive mixture of petroleum jelly and paraffin $(9: 1, \mathrm{wt} / \mathrm{wt})$ dissolved in sufficient toluene (approximately $3 \mathrm{ml}$ per $50 \mathrm{~g}$ of mixture) to result in a thick consistency. Tapes were removed weekly, cut into $48-\mathrm{mm}$ lengths, scored at hourly intervals, stained with aniline blue in glycerol $(0.14 \mathrm{mg}$ of aniline blue, $20 \mathrm{ml}$ of distilled water, $15 \mathrm{ml}$ of glycerol, and $10 \mathrm{ml}$ of $85 \%$ lactic acid), mounted on glass slides under 22-by-50-mm cover slips, and sealed using Cytoseal (Richard-Allan Scientific, Kalamazoo, MI). P. cubensis sporangia were examined at $\times 400$ magnification, identified based on morphological characteristics (57), and counted. Although $P$. humuli sporangia cannot be separated by morphological characteristics from those of $P$. cubensis (11), Michigan's limited production of hops (3) makes it unlikely that $P$. humuli sporangia were present in significant numbers on tapes. Sporangial counts were unavailable for more than $2 \mathrm{~h}$ on each of the following dates due to equipment malfunctions: Allegan County: 25 to 28 June, 25 July to 1 August, and 9 to 13 August 2007; Bay County: 11 to 14 July 2009; Cass County: 24 to 25

Table 1. Dates of the sampling period ( $n=$ number of days), frequency (\%) of days with at least one Pseudoperonospora cubensis sporangium detected (trapping days), date that the first sporangium was detected (First sp.), total number of sporangia per cubic meter sampled during the sampling period (Total sp.), and the maximum daily airborne sporangial concentration (Conc.) at each site in five counties in Michigan sampled from 2006 to $2009^{\mathrm{a}}$

\begin{tabular}{|c|c|c|c|c|c|c|}
\hline \multirow[b]{2}{*}{ County, year } & \multirow[b]{2}{*}{ Sampling days (n) } & \multirow[b]{2}{*}{ Trapping days (\%) } & \multirow[b]{2}{*}{ First sp. } & \multirow[b]{2}{*}{ Total sp. } & \multicolumn{2}{|c|}{ Maximum concentration } \\
\hline & & & & & Conc. (sp./m³/day) & Date \\
\hline \multicolumn{7}{|l|}{ Allegan } \\
\hline 2006 & 16 June to 18 August (64) & 82 & 17 June & 29,335 & 5,115 & 13 August \\
\hline 2007 & 11 June to 27 August (78) & 60 & 13 June & 910 & 140 & 20 June \\
\hline 2008 & 18 July to 18 September (63) & 94 & 18 July & 1,135 & 97 & 15 September \\
\hline 2009 & 3 June to 2 September (93) & 85 & 3 June & 1,598 & 370 & 30 August \\
\hline \multicolumn{7}{|c|}{ - } \\
\hline 2006 & 14 June to 15 August (63) & 89 & 18 June & 1,583 & 178 & 6 August \\
\hline 2007 & 14 June to 30 August (78) & 42 & 15 June & 685 & 278 & 6 August \\
\hline 2008 & 5 June to 26 August (83) & 73 & 14 June & 1,490 & 87 & 12 August \\
\hline 2009 & 2 June to 28 August (88) & 92 & 3 June & 3,083 & 898 & 17 August \\
\hline \multicolumn{7}{|l|}{ Cass } \\
\hline 2006 & 16 June to 16 August (62) & 100 & 16 June & 7,965 & 398 & 30 July \\
\hline 2007 & NM & $\mathrm{NM}$ & NM & NM & NM & $\mathrm{NM}$ \\
\hline 2008 & 3 June to 18 September (108) & 74 & 19 June & 780 & 40 & 23 August \\
\hline 2009 & 3 June to 2 September (93) & 85 & 3 June & 1,187 & 168 & 23 August \\
\hline \multicolumn{7}{|l|}{ Monroe } \\
\hline 2006 & 15 June to 6 November (145) & 91 & 15 June & 863,495 & 62,013 & 19 July \\
\hline 2007 & 7 June to 27 August (82) & 50 & 8 June & 340,515 & 64,840 & 11 August \\
\hline 2008 & 7 June to 3 September (89) & 88 & 14 June & 89,823 & 24,692 & 12 July \\
\hline 2009 & 1 June to 2 September (95) & 86 & 1 June & 2,040 & 465 & 4 June \\
\hline \multicolumn{7}{|l|}{ Saginaw } \\
\hline 2006 & 26 June to 15 August (51) & 100 & 26 June & 2,357 & 948 & 10 August \\
\hline 2007 & 14 June to 30 August (78) & 69 & 14 June & 4,160 & 1,425 & 5 August \\
\hline 2008 & 5 June to 16 September (104) & 82 & 12 June & 7,058 & 2,382 & 5 September \\
\hline 2009 & 2 June to 28 August (88) & 85 & 2 June & 1,853 & 608 & 21 August \\
\hline
\end{tabular}

${ }^{\mathrm{a}} \mathrm{NM}=$ not monitored. 
June, 10 to 11 July, and 31 July 2008; and Monroe County: 4 to 11 July 2007 and 29 June 2008. Sporangial counts were converted to sporangia per cubic meter per hour.

Hourly environmental data for temperature $\left({ }^{\circ} \mathrm{C}\right)$, RH $(\%)$, leaf wetness at the canopy level ( $45^{\circ}$ angle facing north), and rainfall $(\mathrm{mm})$ were measured by a Watchdog model 450 data logger, leaf wetness sensor, and tipping bucket rain gauge (Spectrum Technologies, Plainfield, IL) in each field in 2008 and 2009 (Table 2). Whereas temperature and $\mathrm{RH}$ data were collected at all sites, leaf wetness data were not collected from the Monroe County site in 2008 and rainfall was only collected from the Monroe County site in 2008 and three of five sites in 2009 (Table 2). Monitoring of environmental conditions began after monitoring of sporangial concentrations was initiated in 2008; specifically, environmental monitoring began on 18 July in Allegan County, 15 July in Bay County, 26 June in Cass County, 10 July in Monroe County, and 15 July in Saginaw County. Environmental conditions were not available for the following times due to equipment malfunctions: Allegan County: 18 July to 21 August 2008 for leaf wetness and 21 July to 12 August 2009 for all environmental parameters; Bay County: 30 July to 4 August, 15 August, and 25 to 26 August 2008 for leaf wetness; and Saginaw County: 2 to 5 June 2009 for leaf wetness. Fields were scouted for presence or absence of disease symptoms or pathogen signs weekly when the tapes were changed, and suspect leaf samples were brought to the Hausbeck Lab at Michigan State University for diagnosis. In addition, grower cooperators throughout Michigan mailed leaf samples from their fields with pathogen signs or downy mildew symptoms to the Hausbeck Lab for diagnosis. The disease was determined to be present in a county when symptoms or signs on a leaf sample were confirmed as downy mildew using stereomicroscopy.

Data analyses. Statistical analyses were performed using SAS (version 9.1; SAS Institute, Inc., Cary, NC). The Proc LOESS procedure was used to perform loess nonparametric regression analyses (12-14) to model seasonal trends for daily sporangial concentrations and daily temporal trends for hourly sporangial concentrations at each site for each year. The smoothing parameter was chosen to minimize a bias-corrected Akaike Information Criterion (33).

For further statistical analysis, each day was divided into six 4-h periods; namely, midnight to $3: 59$, 4:00 to $7: 59,8: 00$ to $11: 59$, 12:00 to $15: 59,16: 00$ to $19: 59$, and $20: 00$ to $23: 59 \mathrm{~h}$. These intervals were chosen based on the trend observed for hourly sporangial concentrations throughout a day (Fig. 1). For each 4-h interval, the average temperature, average $\mathrm{RH}$, number of hours of leaf wetness, total rainfall, and concentration of sporangia were calculated. Sporangial concentrations were $\log$ transformed $(\ln (\mathrm{x})+0.1)$ prior to correlation and regression analyses to stabilize the variance. The PROC CORR procedure was used to calculate Pearson's correla- tion coefficients (52) among airborne sporangial concentrations and the environmental parameters monitored. Correlations with $P$ $\leq 0.0125$ were considered statistically significant using a Bonferroni correction as four tests were being simultaneously conducted $(P \leq 0.05 / 4)(44)$.

The 4-h sporangial concentrations and corresponding environmental parameters were time series that are temporally autocorrelated (6). Time series analyses are used to study changes of a variable through time in an attempt to uncover patterns and relationships in the data. Using the PROC autoregressive moving average (ARIMA) procedure, regression analyses were completed, regressing sporangial concentrations on weather variables assuming an autoregressive (AR) moving average (MA) error structure $(7,42)$. The mean was subtracted from each time series prior to analysis, and each series was checked for stationarity, defined as the expected values of the series and its autocovariance function independent of time, using plots of the series and its autocorrelation function. Differencing (I) was completed for nonstationary series prior to development of ARIMA models. Differencing removes trends from the time series by taking the difference of the series from one period to another ( $\mathrm{I}=$ the number of lags) (8). Models were selected using Akaike Information Criterion (1) to measure goodness of fit. Lags (time periods prior to the current time period) of up to $20 \mathrm{~h}$ (five 4-h periods) were permitted for each environmental factor to allow for the influence of environment on pathogen sporulation in the hours prior to sporangial detection. Variables with $P \leq 0.05$ were considered statistically significant.

\section{Results}

Sporangia were detected within 4 days of spore sampling at all of the sites monitored in 2006, 2007, and 2009 (Table 1). For the 2008 sites, at which sampling began in early June, sporangia were first detected in mid-June. At the Allegan County site in 2008, sampling did not begin until mid-July and spores were trapped on the day that sampling began (Table 1; Fig. 1). Airborne sporangial concentrations varied greatly throughout the season each year; airborne sporangia were detected on 42 to $100 \%$ of the days monitored for each site each year. Generally, more sporangia were detected in late July, throughout August, and in early September than in June or early July, although there were some definite exceptions to this (Fig. 1). Up to 64,840 sporangia $/ \mathrm{m}^{3}$ were detected in a single day, which occurred at the Monroe site in 2007 (Table 1; Fig. $1)$. The site with the greatest number of seasonal sporangia detected ( $>80,000$ total) was the Monroe site in 2006, 2007, and 2008, followed by the Bay site in 2009 (>3,000 sporangia total). In 2009 , the Monroe County site was planted to pumpkin instead of cucumber, and the number of spores detected at this site was considerably lower than in the previous 3 years (Table 1 ).

Table 2. Pearson's correlation coefficients (r) between 4-h durations of total log-transformed Pseudoperonospora cubensis sporangial concentrations detected and 4-h durations of total or average corresponding environmental factors in commercial cucurbit fields in five counties in Michigan in 2008 and $2009^{\mathrm{a}}$

\begin{tabular}{|c|c|c|c|c|c|}
\hline \multirow[b]{2}{*}{ Factors $^{\mathrm{c}}$} & \multicolumn{5}{|c|}{ County (one site/county) } \\
\hline & Allegan & Bay & Cass & Monroe & Saginaw \\
\hline \multicolumn{6}{|l|}{2008} \\
\hline RH (\%) & $-0.45 * * *$ & $-0.31 * * *$ & $-0.30 * * *$ & $-0.16^{* * *}$ & $-0.32 * * *$ \\
\hline Temp $\left({ }^{\circ} \mathrm{C}\right)$ & $0.38 * * *$ & $0.37 * * *$ & $0.31 * * *$ & $0.35^{* * *}$ & $0.30 * * *$ \\
\hline LW (h wet) & $-0.39 * * *$ & $-0.26 * * *$ & $-0.14 * *$ & NM & $-0.31 * * *$ \\
\hline Rain (mm) & NM & NM & NM & NM & NM \\
\hline \multicolumn{6}{|l|}{2009} \\
\hline RH (\%) & $-0.21 * * *$ & $-0.17 * * *$ & $-0.21 * * *$ & $-0.23 * * *$ & $-0.20 * * *$ \\
\hline Temp $\left({ }^{\circ} \mathrm{C}\right)$ & $0.23 * * *$ & $0.32 * * *$ & $0.23 * * *$ & $0.17 * * *$ & $0.20 * * *$ \\
\hline LW (h wet) & $-0.22 * * *$ & $-0.28 * * *$ & $-0.22 * * *$ & $-0.17 * * *$ & $-0.22 * * *$ \\
\hline Rain (mm) & -0.08 & -0.03 & NM & NM & -0.07 \\
\hline
\end{tabular}



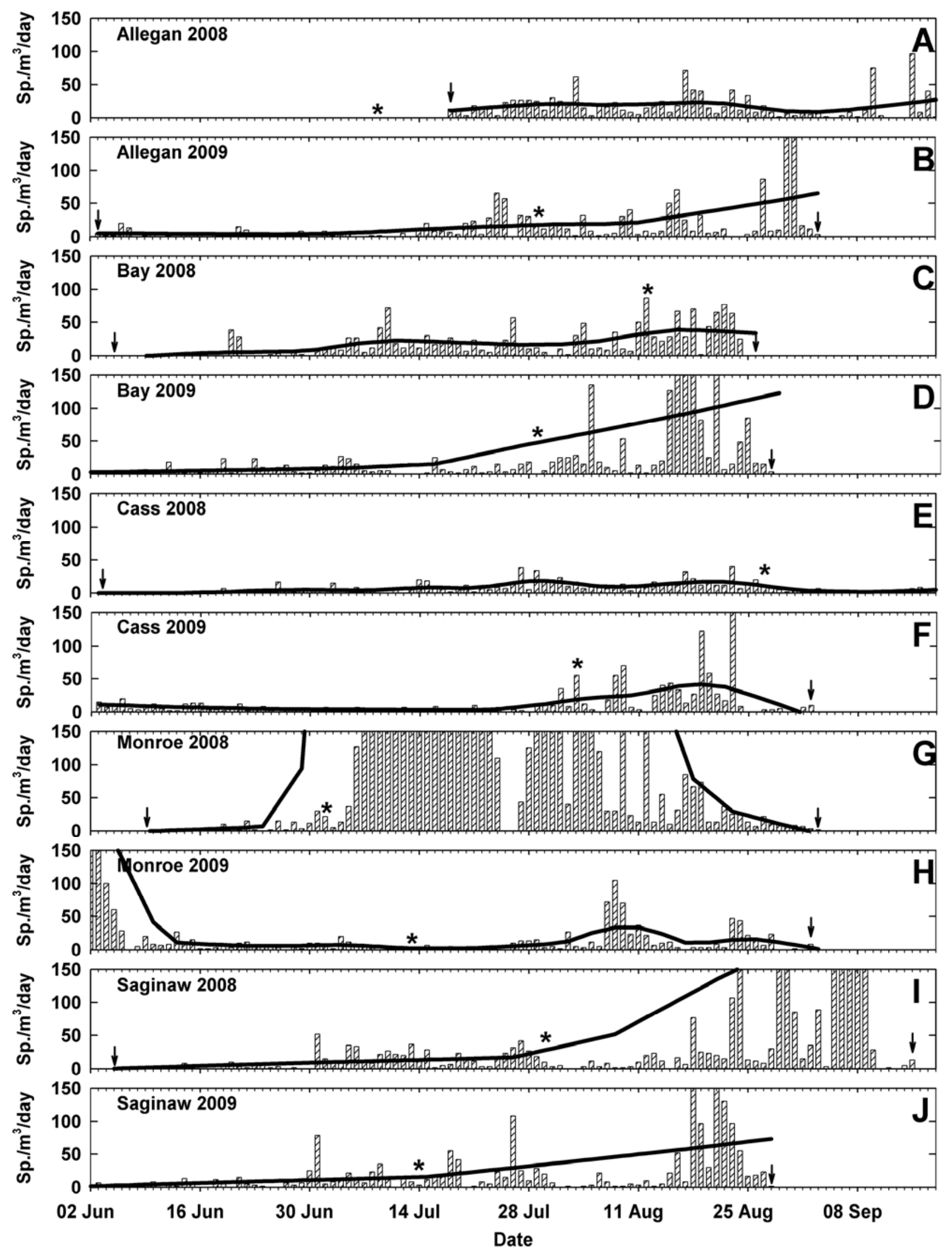

Fig. 1. Daily concentrations of Pseudoperonospora cubensis sporangia detected in A, C, E, G, and I, 2008 and B, D, F, H, and J, 2009 at the A and B, Allegan; C and D, Bay; $\mathbf{E}$ and F, Cass; $\mathbf{G}$ and $\mathbf{H}$, Monroe; and I and J, Saginaw County sites over the course of the sampling season (bars shown). Asterisks denote the date that downy mildew was first confirmed to be present in any cucurbit field in the county. Arrows denote the date of sampling initiation or termination if these dates were after 2 June or before 18 September. Sporangial concentrations $>150$ sporangia/m³/day were cropped from the figure. Curves were fitted by locally weighted regression (PROC LOESS) to relate time of the season (2 June to 18 September) to predicted sporangial concentrations (sporangia/m $3 /$ day) to illustrate seasonal trends. Outliers were cropped from the figure but were included in LOESS analyses. 
The concentrations of airborne sporangia detected showed a marked daily trend, with the highest hourly sporangial concentrations between 8:00 and 13:00 $\mathrm{h}$ and a pronounced peak at approximately 10:00 h, when sporangial counts were modeled using loess nonparametric regression (Fig. 2). Diurnal cycles were also apparent for average $\mathrm{RH}$, average temperature, and total leaf wetness, with average RH and total leaf wetness greatest at night and in the early morning, and the highest average temperatures recorded midday (Fig. 3).

Airborne sporangial concentrations measured in $4-\mathrm{h}$ periods were positively correlated with average temperature $(r=0.17$ to
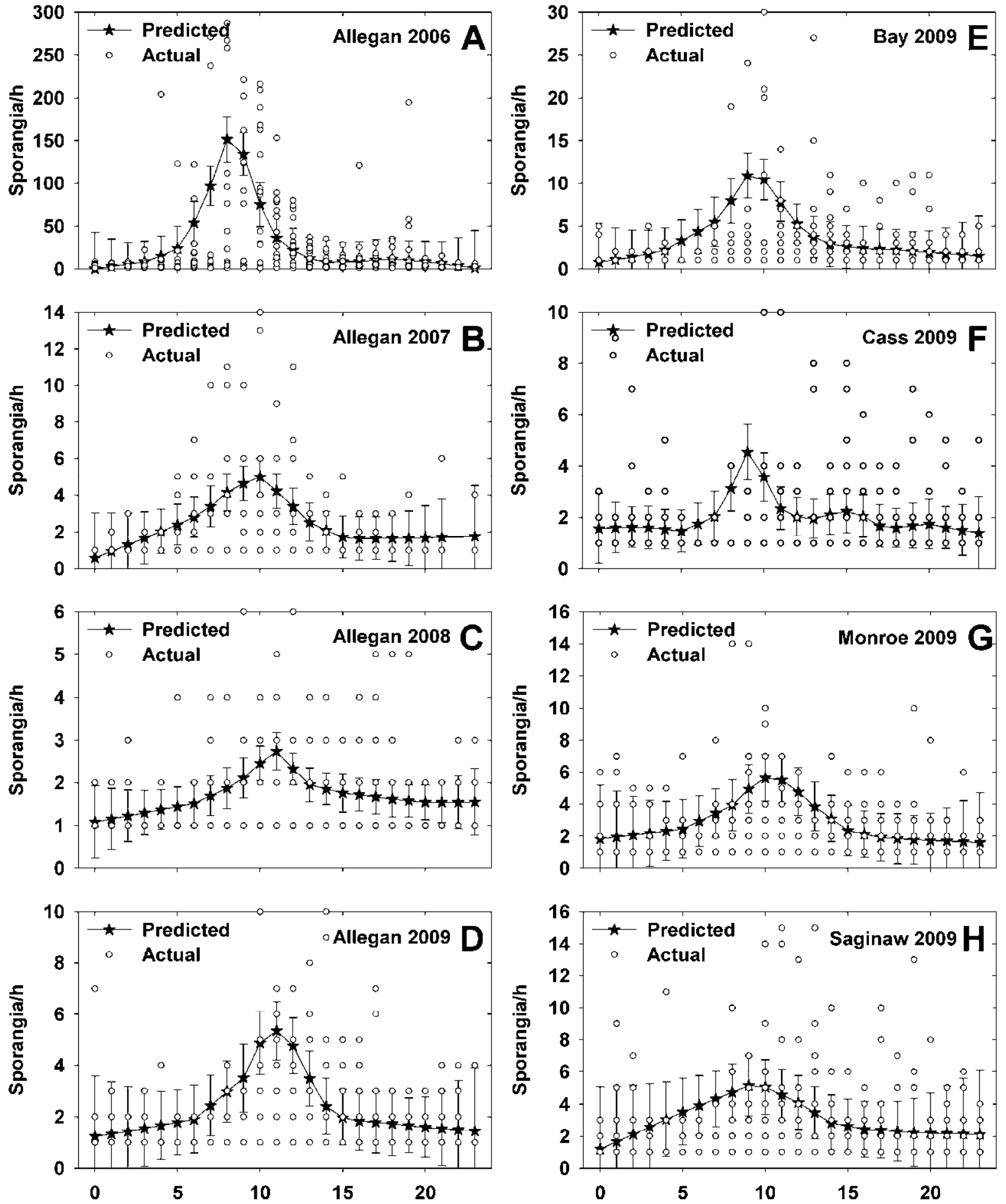

Time of day (h)

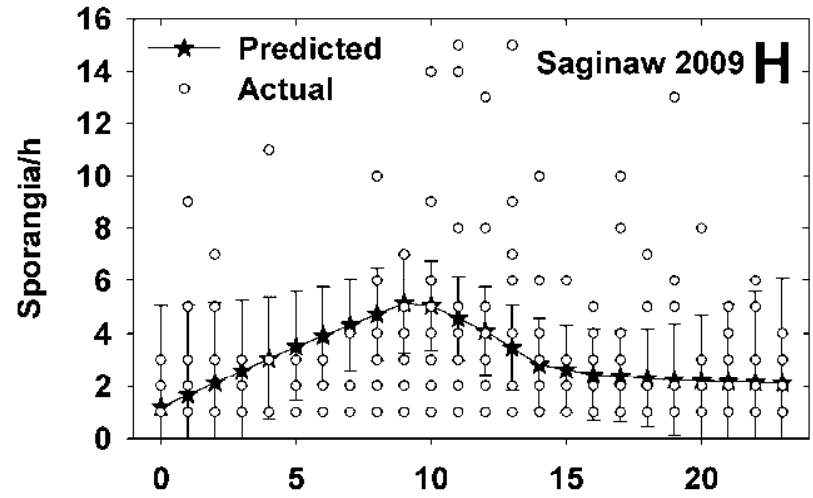

Time of day (h)

Fig. 2. Daily periodicity of Pseudoperonospora cubensis sporangia in Michigan at the Allegan County site in A, 2006; B, 2007; C, 2008; and D, 2009; and at the E, Bay County; F, Cass County; G, Monroe County; and H, Saginaw County sites in 2009. Dots represent actual sporangial counts ( $\times 1.67$ for sporangia/m $\mathrm{m}^{3}$ air). The curve was generated using predicted values for sporangial counts from fitted loess nonparametric regression models. Models were fitted using more than $180 \mathrm{~h}$ of counts of the number of airborne sporangia for each site-year. Error bars represents the 95\% confidence interval around this fit. Outliers were cropped from the figure but were included in LOESS analyses. Note differences in the $y$-axes. Hour zero represents midnight on the $x$-axis. Daily periodicity at other site-years is similar to those presented. 
$0.38, P<0.0001)$ and negatively correlated with both average RH $(r=-0.16$ to $-0.45, P \leq 0.0046)$ and total leaf wetness $(r=-0.14$ to $-0.39, P \leq 0.0001)$ in the same 4 -h periods at all of the sites monitored in 2008 and 2009 (Table 2). Rainfall was not significantly correlated with sporangial concentrations at any of the sites monitored in 2009 ( $r=-0.08$ to $0.11, P \geq 0.0396$ ).

When ARIMA regression models were developed to explore the relationships between airborne sporangial concentrations and environmental factors for all the sites monitored in 2008 and 2009, RH was included in all of the models (Table 3 ). There was a negative relationship between sporangial concentrations in a 4-h period and average RH in the same 4-h period (slope, $b=-0.03$ to $-1.34, P<$ 0.0496), and this relationship was observed at Allegan, Cass, and Saginaw Counties in 2008 and at Bay, Cass, Monroe, and Saginaw Counties in 2009 (Table 3). In contrast, average RH in the 4-h period immediately preceding the 4 -h period of sporangia detection (one 4-h lag) was positively associated with the number of sporangia detected at Bay County in $2008(b=0.14, P=0.0064)$, Allegan County in $2009(b=0.20, P=0.0307)$, and Saginaw County in $2009(b=0.20, P=0.0363)$ and negatively associated with sporangial concentrations at Cass County in $2008(b=-0.03, P=0.0098)$ and Saginaw County in $2008(b=-1.71, P=0.0099)$. Average RH in two 4-h lags prior to sporangial detection was positively associated with the number of sporangia detected at Bay County $(b=$ $0.21, P<0.0001)$ and Monroe County $(b=11.58, P=0.0127)$ in
2008. Average temperature in the 4-h period immediately preceding the 4-h period of sporangia detection was negatively associated with the number of sporangia detected at Bay County in $2008(b=$ $-0.96, P<0.0001)$ and Saginaw County in $2008(b=-7.62, P=$ 0.0003 ) and positively associated with airborne sporangial concentrations at Allegan County in $2009(b=0.96, P=0.0117)$. Additional environmental parameters were included in the model for two of the site years. Specifically, leaf wetness $(b=-1.20, P=$ $0.0024)$ in the 4-h period immediately preceding sporangial detection was included for Bay County in 2008, and average RH $(b=$ $-12.25, P=0.0063)$ and total rainfall $(b=538.89, P=0.0002)$ in the 4-h lag preceding sporangial detection for Monroe County in 2008 .

\section{Discussion}

Growers of cucumber in Michigan and nearby states have had to adopt rigorous fungicide application programs since 2005 to protect their crops from downy mildew (49). Other susceptible cucurbits grown in Michigan include melon, squash, and pumpkin $(2,54)$. Growers must be vigilant in disease scouting and apply downy-mildew-specific fungicides when the pathogen has been detected in their field or in nearby growing regions. P. cubensis produces copious sporangia (46), which are liberated from the host following a reduction in RH (36) and may be wind-dispersed over great distances (40). P. cubensis cannot survive without a living
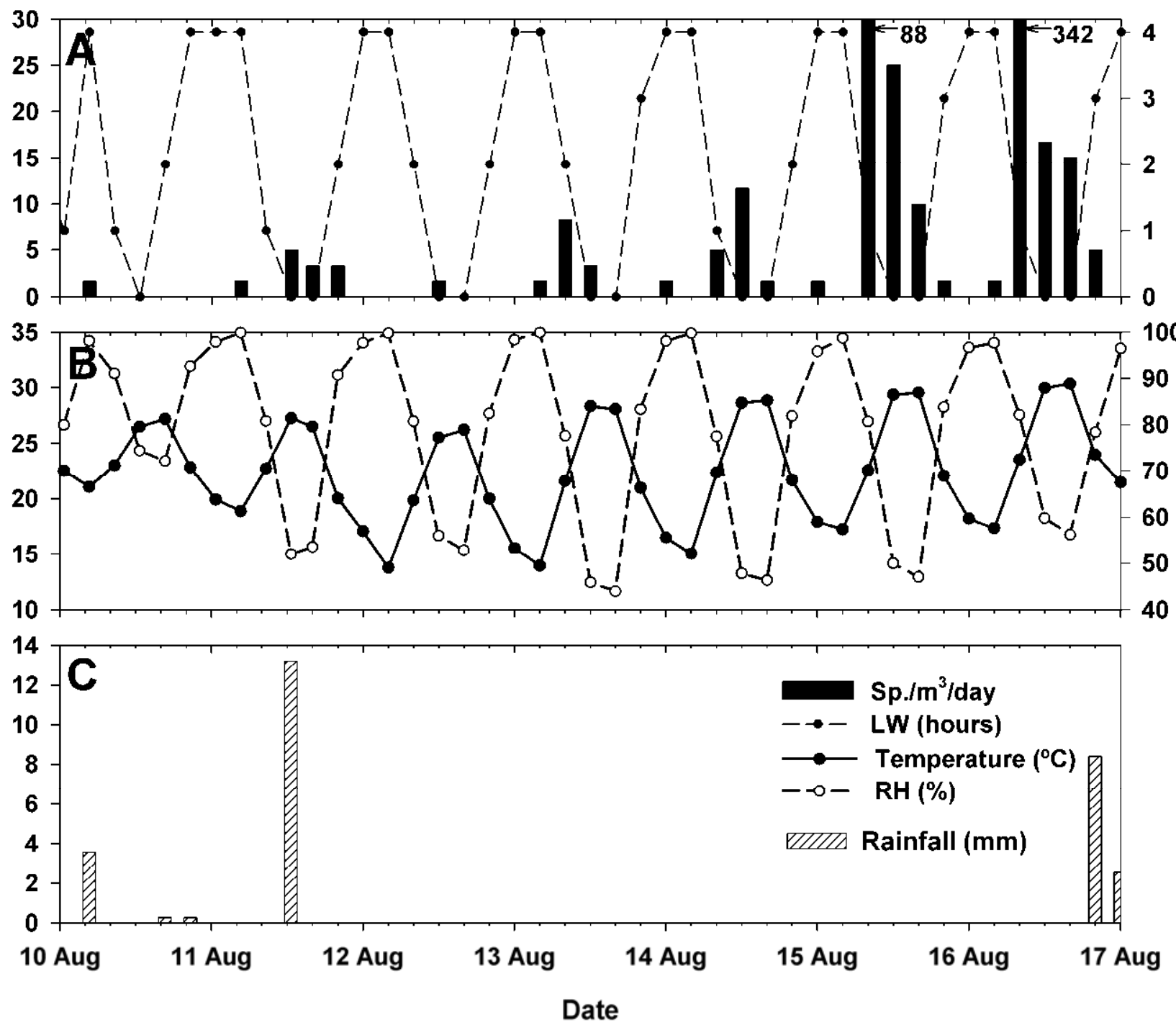

Fig. 3. Four-hour total airborne Pseudoperonospora cubensis sporangial concentrations, average temperature $\left({ }^{\circ} \mathrm{C}\right)$, average relative humidity $(\mathrm{RH}, \%)$, and total leaf wetness (LW, number of hours of leaf wetness) for a representative week at the Bay County site in Michigan in 2009. This is a representative week when sporangia were detected and rainfall occurred. 
host and, thus, cannot overwinter outdoors in temperate regions like Michigan; therefore, long-distance dispersal of sporangia is necessary for downy mildew to become established in these regions each growing season. $P$. cubensis could overwinter in yearround cucumber production greenhouses (54) such as those in southern Ontario but Michigan does not have a greenhouse-grown cucumber industry (M. K. Hausbeck, personal communication). Hence, in states like Michigan, it is important to understand the temporal dynamics of airborne inocula because the arrival of sporangia is the first step toward infection and epidemic initiation. Spore trapping in Michigan was initiated in 2006 in response to grower concerns of expenses associated with fungicide applications for downy mildew control. Airborne sporangial concentrations have been described as the most important biotic factor determining disease onset (15).

Although P. cubensis sporangial concentrations have previously been associated with some environmental conditions in central Florida (51) and Israel (20), the short-term duration of P. cubensis trapping in these studies and the differences in climate between Michigan, central Florida, and Israel suggested that a study relating environmental conditions and airborne sporangial concentrations in Michigan could be valuable. In addition, some suggest that a new pathotype or new species $(22,47,50)$ is responsible for recent downy mildew epidemics.

Sporangia were detected the day of or within a few days of trapping initiation in 2006, 2007, and 2009, indicating that inocula were likely present before sampling began in those years. Sporangia were detected throughout the growing season, which differs from what was observed in a study in Florida, where sporangial trapping in a watermelon field only detected sporangia for 30 days toward the end of the growing season (June) each year, even though concentrations were monitored from January through July (51). Sporangial concentrations in this Michigan study were generally higher at the end of the growing season than at the beginning, a more subtle but similar trend to what was observed in the study by Schenck, when sporangia were only detected during the month of June, at the end of the watermelon growing season in Florida (51). At the Monroe County site in 2006, when trapping was continued until early November, sporangia were detected until mid-October (data not shown). The lack of detectable sporangial concentrations in late October or early November that season was likely due to crops being killed by frost (data not shown); a similar pattern was observed for Peronospora tabacina in the northeastern United States (45). Our results suggest that fungicide applications in Michigan should begin as soon as the crop is planted in June or July, because sporangia may be present by mid-June or earlier. Disease will develop when viable sporangia are present and envi- ronmental conditions are favorable. Future studies that relate sporangial concentrations and environmental conditions to disease onset and progress are necessary to determine whether fungicide applications can be delayed or avoided under certain environmental conditions or when sporangial concentrations are below a certain threshold.

Fluctuations in hourly sporangial counts throughout the day were observed, with peak concentrations occurring in the morning and early afternoon, as shown by this study and previous studies on Pseudoperonospora cubensis $(20,51)$ and other downy mildew pathogens $(9,29)$. Air turbulence also peaks around mid-morning, which allows for long-distance movement of sporangia (4). Differences in sporangial release throughout the day may be due to variations in solar irradiance, wind speed or turbulence, $\mathrm{RH}$, and changing spore maturity throughout the day, as has been observed for Peronospora tabacina sporangia (58). Leach et al. (37) found that red-to-infrared radiation enhanced $P$. destructor sporangial release, and $\mathrm{Su}$ et al. (53) found that light initiation and a decrease in $\mathrm{RH}$ were associated with sporangial release in Bremia lactucae. Cohen (16) suggested that light and temperature do not influence dispersal of Pseudoperonospora cubensis sporangia significantly. Schenck (51) did not detect airborne P. cubensis sporangia before 6:00 h and after 16:00 $\mathrm{h}$ in a watermelon field; in our study, a limited number of sporangia ( 0 to 768 sporangia in an hour) were detected in the evening and very early morning. In a single hour after 16:00 and before $6: 00 \mathrm{~h}, 0$ to 18,500 sporangia were detected. Schenck placed his spore traps approximately $1.2 \mathrm{~m}$ above the ground (51) whereas, in our study, the orifice of the spore trap was approximately $0.5 \mathrm{~m}$ above the ground, which might explain some of the differences in results between studies.

In this study, total 4-h airborne sporangial concentrations were positively correlated with average air temperature and negatively correlated with both average RH and total leaf wetness in the same 4-h period. In a previous study with $B$. lactucae, sporangial release was also significantly correlated with increased temperature and a drop in RH (10). It has previously been noted that temperature had little effect on dispersal of $P$. cubensis sporangia (16). However, increased temperature and RH result in rapid maturation of sporangia $(17,19)$, which may explain the positive relationship between average temperature and airborne sporangial concentrations observed in our study. Additionally, if the P. cubensis population causing the recent epidemics in the United States is a different pathotype or species, then the current population may sporulate or survive better at high temperatures than the $P$. cubensis isolates studied previously. Controlled temperature studies using recent isolates of $P$. cubensis are necessary to determine whether this is the case, especially as temperature and RH are correlated.

Table 3. Autoregressive moving average (ARIMA) regression models relating 4-h Pseudoperonospora cubensis sporangial concentrations measured at time period $\mathrm{t}$ (six time periods/day) with environmental parameters measured for the same 4-h period and for a lag of up to five 4-h periods prior to the sporangial sampling period, in commercial cucurbit fields in five counties in Michigan in 2008 and 2009

\begin{tabular}{|c|c|}
\hline Year, county & ARIMA $^{b}$ \\
\hline \multicolumn{2}{|l|}{2008} \\
\hline Allegan & $\mathrm{Sp}_{\mathrm{t}}=-0.03 \mathrm{RH}_{\mathrm{t}}+\mathrm{Z}$ where $\mathrm{Z}=-0.35 \mathrm{z}_{\mathrm{t}-1}$ where $\mathrm{RH}$ had $(1,6)$ differencing prior to analysis \\
\hline Bay & $\mathrm{Sp}_{\mathrm{t}}=-0.96 \mathrm{Temp}_{\mathrm{t}-1}+0.14 \mathrm{RH}_{\mathrm{t}-1}+0.21 \mathrm{RH}_{\mathrm{t}-2}-1.20 \mathrm{LW}_{\mathrm{t}-1}$, where Temp, $\mathrm{RH}$, and LW $(1,6)$ and $\mathrm{Sp}(6)$ had differencing prior to analysis \\
\hline Cass & $\begin{array}{l}\mathrm{Sp}_{\mathrm{t}}=-0.3 \mathrm{RH}_{\mathrm{t}}-0.03 \mathrm{RH}_{\mathrm{t}-1}+\mathrm{Z} \text { where } \mathrm{Z}=0.97 \mathrm{z}_{\mathrm{t}-1}-0.94 \mathrm{z}_{\mathrm{t}-2}+0.57 \mathrm{e}_{\mathrm{t}-2}-0.67 \mathrm{e}_{\mathrm{t}-3} \text { where Sp and } \mathrm{RH} \text { had }(1,6) \text { differencing prior to } \\
\text { analysis }\end{array}$ \\
\hline Monroe & $\mathrm{Sp}_{\mathrm{t}}=11.58 \mathrm{RH}_{\mathrm{t}-2}-12.25 \mathrm{RH}_{\mathrm{t}-4}+538.89 \mathrm{Rain}_{\mathrm{t}-4}+\mathrm{Z}$ where $\mathrm{Z}=0.31 \mathrm{e}_{\mathrm{t}-2}$ where $\mathrm{RH}(1,6)$ and $\mathrm{Sp}(6)$ had differencing prior to analysis \\
\hline Saginaw & $\begin{array}{l}\mathrm{Sp}_{\mathrm{t}}=-7.89 \mathrm{Temp}_{\mathrm{t}}-1.34 \mathrm{RH}_{\mathrm{t}}-1.71 \mathrm{RH}_{\mathrm{t}-1}+\mathrm{Z} \text { where } \mathrm{Z}=-0.98 \mathrm{z}_{\mathrm{t}-1}+-0.98 \mathrm{z}_{\mathrm{t}-2}-0.61 \mathrm{e}_{\mathrm{t}-2}-0.55 \mathrm{e}_{\mathrm{t}-3}+0.12 \mathrm{e}_{\mathrm{t}-4} \text { where Sp and } \mathrm{RH} \text { had }(6) \\
\text { differencing prior to analysis }\end{array}$ \\
\hline \multicolumn{2}{|l|}{2009} \\
\hline Allegan & $\mathrm{Sp}_{\mathrm{t}}=0.96 \mathrm{Temp}_{\mathrm{t}-1}+0.20 \mathrm{RH}_{\mathrm{t}-1}+\mathrm{Z}$ where $\mathrm{Z}=0.79 \mathrm{z}_{\mathrm{t}-1}+1.22 \mathrm{e}_{\mathrm{t}-2}-0.47 \mathrm{e}_{\mathrm{t}-3}+0.16 \mathrm{e}_{\mathrm{t}-4}$ where $\mathrm{RH}$ had (1) differencing prior to analysis \\
\hline Bay & $\mathrm{Sp}_{\mathrm{t}}=\mathrm{Z}$ where $\mathrm{Z}=0.88 \mathrm{z}_{\mathrm{t}-1}+0.95 \mathrm{e}_{\mathrm{t}-1}$ \\
\hline Cass & $\mathrm{Sp}_{\mathrm{t}}=-0.05 \mathrm{RH}_{\mathrm{t}}+\mathrm{Z}$ where $\mathrm{Z}=0.74 \mathrm{z}_{\mathrm{t}-1}+0.21 \mathrm{z}_{\mathrm{t}-2}+0.98 \mathrm{e}_{\mathrm{t}-1}$ where $\mathrm{RH}$ had $(1,6)$ differencing prior to analysis \\
\hline Monroe & $\mathrm{Sp}_{\mathrm{t}}=-0.16 \mathrm{RH}_{\mathrm{t}}+\mathrm{Z}$ where $\mathrm{Z}=0.64 \mathrm{z}_{\mathrm{t}-1}+0.21 \mathrm{z}_{\mathrm{t}-2}+0.94 \mathrm{e}_{\mathrm{t}-1}$ where $\mathrm{RH}$ had $(1,6)$ differencing prior to analysis \\
\hline Saginaw & $\mathrm{Sp}_{\mathrm{t}}=-0.18 \mathrm{RH}_{\mathrm{t}}+0.20 \mathrm{RH}_{\mathrm{t}-1}+\mathrm{Z}$ where $\mathrm{Z}=0.92 \mathrm{z}_{\mathrm{t}-1}+0.96 \mathrm{e}_{\mathrm{t}-1}$ where $\mathrm{RH}$ had $(1,6)$ differencing prior to analysis \\
\hline
\end{tabular}

${ }^{a}$ Each day was divided into six 4-h periods: 0:00 to 3:59, 4:00 to 7:59, 8:00 to 11:59, 12:00 to 15:59, 16:00 to 19:59, and 20:00 to 23:59 h. These intervals were chosen based on the daily trend observed for hourly sporangial concentrations.

${ }^{\mathrm{b}} \mathrm{Sp}_{\mathrm{t}}=$ sporangia $/ \mathrm{m}^{3} / 4-\mathrm{h}$ time period $(\mathrm{t}) ; \mathrm{RH}=$ average relative humidity $(\%) ; \mathrm{z}_{\mathrm{t}}$ and $\mathrm{e}_{\mathrm{t}}$ are the moving average and autoregressive error terms, respectively; Temp $=$ average temperature $\left({ }^{\circ} \mathrm{C}\right) ; \mathrm{LW}=$ total number of $\mathrm{h}$ of leaf wetness; and Rain $=$ total rainfall $(\mathrm{mm})$. 
In this study, $\mathrm{RH}$ was the most common factor in the ARIMA models generated to regress $P$. cubensis sporangial concentrations against environmental factors, and a negative relationship was observed between average $\mathrm{RH}$ in a 4-h period and sporangial concentrations in the same 4-h period. When mean 4-h sporangial concentrations were plotted against average $\mathrm{RH}$ values, we observed that a decrease in $\mathrm{RH}$ resulted in an apparent increase in the number of sporangia released to the air. A similar relationship with RH has been observed for the release of $P$. destructans sporangia (37).

In this study, leaf wetness was negatively correlated with airborne sporangial concentrations. A previous study that monitored $P$. cubensis sporangial concentrations in a single cucumber field that had not been treated with fungicides in Israel noted that sporangia were not trapped following a dewless evening (20). Unfortunately, sporangial concentrations were only monitored for 10 days in early September in the Israeli study, a period when little fluctuation occurred in environmental conditions. In a study in a single watermelon field that had not been treated with fungicides in Florida, more sporangia were collected after the dew had dried (51), which supports the results observed in this study. Rainfall was not significantly correlated with sporangial concentrations at any of the three sites monitored in 2009 and at the one site monitored in 2008.

Overall, both correlation analyses and ARIMA regression models demonstrate that ambient $\mathrm{RH}$ greatly impacts the dispersal and concentration of airborne sporangia. Both temperature and leaf wetness appear to influence airborne sporangial concentrations as well. Future studies that focus on determining the relationships between sporangial concentrations, environmental factors, and disease onset and progress in fields with and without fungicide applications could be a next step to use environmental conditions or sporangial concentrations to guide fungicide applications.

\section{Acknowledgments}

This research is based upon work supported by the NCR-IPM award number 2003-51120-02111 S4256, Project Green award numbers GR007-077 and GR06-099D, and the Pickle and Pepper Research Committee of Michigan State University, Pickle Packers International, Inc. We thank B. Webster, S. Hill, S. Glaspie, A. Pianosi, and H. Sweet for technical assistance; W. Wang for help with statistical analyses; S. Linderman for editing tables and figures; and L. Quesada-Ocampo and T. Enzenbacher for critical review of the manuscript.

\section{Literature Cited}

1. Akaike, H. 1974. A new look at the statistical model identification. IEEE Trans. Automat. Contr. 19:716-723.

2. Anonymous. 2009. National Online Statistics. in: Secondary National Online Statistics.

3. Anonymous. 2009. Online Statistics. U.S. Dep. Agric. Natl. Agric. Stat. Serv.

4. Aylor, D. E. 1990. The role of intermittent wind in the dispersal of fungal pathogens. Annu. Rev. Phytopathol. 28:73-92.

5. Bains, S. S., and Jhooty, J. S. 1976. Over wintering of Pseudoperonospora cubensis causing downy mildew of muskmelon. Indian Phytopathol. 29:213-214.

6. Box, G. E. P., and Jenkins, G. M. 1976. Time Series Analysis: Forecasting and Control. Holden-Day, San Francisco.

7. Box, G. E. P., and Tiao, G. C. 1975. Intervention analysis with applications to economic and environmental problems. J. Am. Stat. Assoc. 70:70-79.

8. Brockwell, P. J., and Davis, R. A. 1991. Time Series: Theory and Methods. Springer-Verlag, New York.

9. Byrne, J. M., Hausbeck, M. K., and Sconyers, L. E. 2005. Influence of environment on atmospheric concentrations of Peronospora antirrhini sporangia in field-grown snapdragon. Plant Dis. 89:1060-1066.

10. Carisse, O., and Philion, V. 2002. Meteorological factors affecting periodicity and concentration of airborne spores of Bremia lactucae. Can. J. Plant Pathol. 24:184-193.

11. Choi, Y. J., Hong, S. B., and Shin, H. D. 2005. A re-consideration of Pseudoperonospora cubensis and $P$. humuli based on molecular and morphological data. Mycol. Res. 109:841-848.

12. Cleveland, W. S. 1979. Robust locally-weighted regression and smoothing scatterplots. J. Am. Stat. Assoc. 74:829-836.

13. Cleveland, W. S., Devlin, S. J., and Grosse, E. 1988. Regression by local fitting. J. Econometrics 37:87-114.

14. Cleveland, W. S., and Grosse, E. 1991. Computational methods for local regression. Stat. Comput. 1:47-62.

15. Cohen, Y. 1977. The combined effects of temperature, leaf wetness, and inoculum concentration on infection of cucumbers with Pseudoperonospora cubensis. Can. J. Bot. 55:1478-1487.

16. Cohen, Y. 1981. Downy mildew of cucurbits. Pages 341-354 in: The Downy Mildews. D. M. Spencer, ed. Academic Press, London.

17. Cohen, Y., and Eyal, H. 1977. Growth and differentiation of sporangia and sporangiophores of Pseudoperonospora cubensis on cucumber cotyledons under various combinations of light and temperature. Physiol. Plant Pathol. 10:93-103.

18. Cohen, Y., Meron, I., Mor, N., and Zuriel, S. 2003. A new pathotype of Pseudoperonospora cubensis causing downy mildew in cucurbits in Israel. Phytoparasitica 31:458-466.

19. Cohen, Y., Perl, M., and Rotem, J. 1971. The effect of darkness and moisture on sporulation of Pseudoperonospora cubensis in cucumbers. Phytopathology 61:594-595.

20. Cohen, Y., and Rotem, J. 1971. Dispersal and viability of sporangia of Pseudoperonospora cubensis. Trans. Br. Mycol. Soc. 57:67-74.

21. Cohen, Y., and Rotem, J. 1971. Field and growth chamber approach to epidemiology of Pseudoperonospora cubensis on cucumbers. Phytopathology 61:736-737.

22. Colucci, S. J., and Holmes, G. J. 2007. Fungicide insensitivity and pathotype determination of Pseudoperonospora cubensis, causal agent of cucurbit downy mildew. (Abstr.) Phytopathology 97:S24.

23. D'Ercole, N. 1975. La peronoospora del cetriolo in coltura protetta. Inf Fitopathol. 25:11-13.

24. Doran, W. L. 1932. Downy mildew of cucumbers. Mass. Agric. Exp. Stn. Bull. 283.

25. Gevens, A. J., and Hausbeck, M. K. 2006. Control of downy mildew of cucumbers with fungicides, 2005. Fungic. Nematicide Tests 61:V062.

26. Hausbeck, M. K. 2009. Downy mildew and Phytophthora control in vine crops. Pages 193-195 in: 2009 Empire State Fruit Veg. Crops Expo, Syracuse, NY.

27. Hausbeck, M. 2010. Managing cucumber diseases in the field. In: Proc. Great Lakes Fruit, Vegetable \& Farm Market Expo. Grand Rapids, MI.

28. Hausbeck, M. K., and Cortright, B. D. 2009. Evaluation of fungicides for control of downy mildew of pickling cucumber, 2007. PDMR 3:V112.

29. Hildebrand, P. D., and Sutton, J. C. 1982. Weather variables in relation to an epidemic of onion downy mildew. Phytopathology 72:219-224.

30. Hiura, M., and Kawada, S. 1933. On the overwintering of Peronoplasmopara cubensis Jpn. J. Bot. 6:507-513.

31. Holmes, G. J., Main, C. E., and Keever, Z. T. 2006. Cucurbit downy mildew: a unique pathosystem for disease forecasting. Pages 69-80 in: Advances in Downy Mildew Research. P. T. N. Spencer-Phillips and M. Jeger, eds. Kluwer Academic Publishers, Dordrecht, The Netherlands.

32. Holmes, G. J., and Thomas, C. E. 2006. The history and re-emergence of cucurbit downy mildew (Abstr.) Phytopathology 99:S171.

33. Hurvich, C. M., Simonoff, J. S., and Tsai, C. L. 1998. Smoothing parameter selection in nonparametric regression using an improved Akaike Information Criterion. J. R. Stat. Soc. Ser. B Stat. Methodol. 60:271-293.

34. Iwata, Y. 1949. Studies on the invasion of cucumber plants by downy mildew. Ann. Phytopathol. Soc. Jpn. 13:60-61. (In Japanese, with English summary)

35. Kanetis, L., Holmes, G. J., and Ojiambo, P. S. 2009. Survival of Pseudoperonospora cubensis sporangia exposed to solar radiation. Plant Pathol. 59:313-323.

36. Lange, L., Eden, U., and Olson, L. W. 1989. Zoosporogenesis in Pseudoperonospora cubensis, the causal agent of cucurbit downy mildew. Nord. J. Bot. 8:497-504.

37. Leach, C. M., Hildebrand, P. D., and Sutton, J. C. 1982. Sporangium discharge by Peronospora destructor: influence of humidity, red-infrared radiation, and vibration. Phytopathology 72:1052-1056.

38. Lebeda, A., and Widrlechner, M. P. 2004. Response of wild and weedy Cucurbita L. to pathotypes of Pseudoperonospora cubensis (Berk. \& Curt.) Rostov. (cucurbit downy mildew). Pages 203-210 in: Advances in Downy Mildew Research. P. T. N. Spencer-Phillips and M. Jeger, eds. Kluwer Academic Publishers, Dordrecht, The Netherlands.

39. Oerke, E. C., Steiner, U., Dehne, H. W., and Lindenthal, M. 2006. Thermal imaging of cucumber leaves affected by downy mildew and environmental conditions. J. Exp. Bot. 57:2121-2132.

40. Ojiambo, P., and Holmes, G. 2011. Spatio-temporal spread of cucurbit downy mildew in the Eastern United States. Phytopathology 101:451-461.

41. Palti, J., and Cohen, Y. 1980. Downy mildew of cucurbits (Pseudoperonospora cubensis): the fungus and its hosts, distribution, epidemiology, and control. Phytoparasitica 8:109-147.

42. Pankratz, A. 1991. Forecasting with Dynamic Regression Models. John Wiley and Sons, New York.

43. Reuveni, R., and Raviv, M. 1997. Control of downy mildew in greenhousegrown cucumbers using blue photoselective polyethylene sheets. Plant Dis. 81:999-1004

44. Rice, W. R. 1989. Analyzing tables of statistical tests. Evolution 43:223225.

45. Rotem, J., and Aylor, D. E. 1984. Development and inoculum potential of Peronospora tabacina in the fall season. Phytopathology 74:309-313.

46. Rotem, J., Cohen, Y., and Bashi, E. 1978. Host and environmental influences on sporulation in vivo. Annu. Rev. Phytopathol. 16:83-101.

47. Runge, F., Choi, Y.-J., and Thines, M. 2010. Phylogenetic investigations in 
the genus Pseudoperonospora reveal overlooked species and cryptic diversity in the P. cubensis cluster. Eur. J. Plant Pathol. 129:135-146.

48. Runge, F., and Thines, M. 2009. A potential perennial host for Pseudoperonospora cubensis in temperate regions. Eur. J. Plant Pathol. 123:483-486.

49. Savory, E. A., Granke, L. L., Quesada-Ocampo, L. M., Varbanova, M., Hausbeck, M. K., and Day, B. 2011. The cucurbit downy mildew pathogen Pseudoperonospora cubensis. Mol. Plant Pathol. 12:217-226.

50. Savory, E. A., Tian, M., Erhardt, C., Hausbeck, M., Hammerschmidt, R., and Day, B. 2008. An integrative approach to characterizing the cucumberPseudoperonospora cubensis interaction. (Abstr.) Phytopathology 98:S140.

51. Schenck, N. C. 1968. Incidence of airborne fungus spores over watermelon fields in Florida. Phytopathology 58:91-94.

52. Sokal, R. R., and Rohlf, F. J. 1995. Biometry, Third ed. W. H. Freeman and Co., New York.
53. Su, H., van Bruggen, A. H. C., and Subbarao, K. V. 2000. Spore release of Bremia lactucae on lettuce is affected by timing of light initiation and decrease in relative humidity. Phytopathology 90:67-71.

54. Thomas, C. E 1996. Downy mildew. Pages 25-27 in: Compendium of Cucurbit Diseases. T. A. Zitter, ed. Cornell University Press, Ithaca, NY.

55. Thomas, C. E., Inaba, T., and Cohen, Y. 1987. Physiological specialization in Pseudoperonospora cubensis. Phytopathology 77:1621-1624.

56. Van Haltern, F. 1933. Spraying cantaloupes for the control of downy mildew and other diseases. Ga. Exp. Stn. Bull. 175.

57. Waterhouse, G. M., and Brothers, M. P. 1981. The taxonomy of Pseudoperonospora. Mycol. Pap. 148:1-18.

58. Yao, C., Arya, S. P., Davis, J., and Main, C. E. 1997. A numerical model of the transport and diffusion of Peronospora tabacina spores in the evolving atmospheric boundary layer. Atmos. Environ. 31:1709-1714. 